\title{
EXPLORING FRAMEWORKS FOR A HISTORY OF EARTH BUILDING IN AOTEAROA NEW ZEALAND
}

\author{
Min Hall ${ }^{1, *}$ \\ ${ }^{1}$ School of Architecture, Unitec Institute of Technology, Auckland, Aotearoa New Zealand - mhall2@ unitec.ac.nz
}

\author{
Commission II - WG II/8
}

KEY WORDS: History, Earth Building, New Zealand, Cob, Sun-dried bricks, Pisé

\begin{abstract}
:
Aotearoa New Zealand has a unique earth building heritage. For centuries, Māori used earth for floors and as a binder for fibrous walling materials. When settlers arrived in the nineteenth century, they brought earth building techniques with them, and in the early days of colonisation, earth buildings were commonplace. Many still survive, but as processed timber became readily available, building in earth declined; by the middle of the twentieth century it had almost ceased. Following renewed interest after World War Two, earth building continued into the twenty-first century, albeit as a non-standard form of construction. Databases compiled by Heritage New Zealand, Miles Allen, and the author, supplemented by accounts from a variety of sources, provide a relatively detailed record of earth buildings from all over Aotearoa but no cohesive history has yet been written. This paper considers possible approaches to writing such a history. Methodologies employed in local and international architectural histories are analysed, and a number of structural hierarchies are identified: for instance, Ronald Rael organises his material firstly by technique and then chronology in Earth Architecture, while Ted Howard uses location and then chronology for his Australasian history, Mud and Man. Information from New Zealand sources is then applied to these frameworks to arrive at an appropriate structural hierarchy for a complete history of earth building in Aotearoa.
\end{abstract}

\section{INTRODUCTION}

Earth is one of the oldest and most prevalent construction materials in the world. In Aotearoa New Zealand it was used by the first inhabitants, Māori, for floors, mounded up to protect walls built out of bio-based materials, and as a binder for some of the latter. When Europeans arrived in the nineteenth century they brought earth building traditions from their homelands with them and adapted them to the new environment. At first, earthen houses were commonplace but as processed timber became readily available earth construction declined. After World War Two interest in earth was revived and since then there has been a small but sustained incidence of earth construction. In 1998 The New Zealand Earth Building standards were published and these have recently been reviewed and updated. To date, no dedicated history of earthen construction in Aotearoa has been written although histories appear as part of other books, such as Ted Howard's Mud and Man, a history of earth building in Australasia, and Miles Allen's Out of the ground, a general book about earth construction in New Zealand. The story of earth building in Aotearoa New Zealand is unique; it is a history that needs to be recorded.

The aim of this paper is to investigate how such a history might be structured. To that end, eleven texts have been analysed in terms of structure and, to a lesser extent, format. Four main structural divisions have been identified: chronological; regional; technique; and typology, and the reasons for different hierarchies of these divisions within the sample group are interrogated. Information from New Zealand sources is then applied to these hierarchies to arrive at an appropriate structural hierarchy for a complete history of earth building in Aotearoa.
In selecting texts for review, priority has been given to those that pertain to either New Zealand or earth construction. Digital formats will also be an important consideration but they have not been investigated in any depth for this paper which focuses primarily on structure.

\section{BACKGROUND}

\subsection{Outline History of Earth Building in New Zealand}

Before the arrival of Europeans, Māori used earth as a component of house construction, but not as a structural element. It was used for floors, as a binder for fibrous wall materials, and as an insulative element by way of mounding up against timber framed walls (Phillips, 1952, p. 15). When settlers arrived from Europe, Australia and China in the nineteenth century they brought with them building techniques including cob, sod, pisé, and sun-dried brick, which were easily translated to the new environment. Earth buildings became an integral part of New Zealand's vernacular architecture, particularly in the South Island, until sawn timber became available in most regions towards the end of the nineteenth century (Hall, 2019). Central Otago, see Figure 1, has a dry climate and is relatively sparsely forested; it is the one region where building in earth has been continuous.

Apart from in Central Otago, very few earth buildings have been recorded from the first half of the twentieth century, but after the Second World War, when building materials were in short supply, a new interest in earth emerged. Both the government and private individuals looked to rammed earth, soil cement and sun-dried brick for constructing houses. Sun-dried bricks continued to be used in Central Otago, but elsewhere it was soil cement that held the most promise for widespread engagement, stemming largely from the experimental work of lecturer

\footnotetext{
* Corresponding author
} 
P.J.(Pip) Alley at the School of Engineering at Canterbury University College (Allen, 1997). Clusters of soil cement houses appeared in Canterbury, Nelson, and Wellington. However, when Government withdrew support in 1959 (Hall, 2017) choosing to focus solely on timber construction, building with earth slowed down but not to a standstill. Building with soil cement continued in Nelson and Canterbury, and with sun-dried brick in Central Otago through the 1960s.

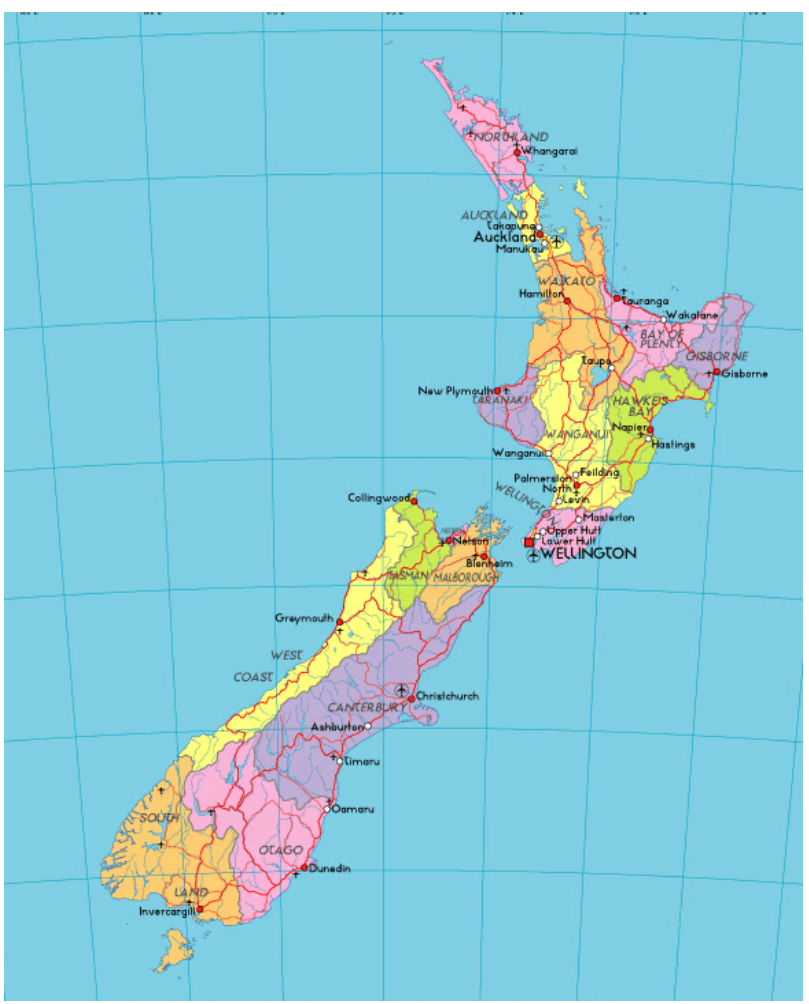

Figure 1. Regions of Aotearoa, New Zealand ${ }^{1}$

The global counterculture movement reached New Zealand in the 1970s and it was then that interest grew in 'alternative' building methods, including earth. In 1971 young architect Graeme North, with assistance from Alley, designed a rammed earth $^{2}$ house for well-known potter, Yvonne Rust. North has since become the leading authority on earth building construction in New Zealand (Hall, 2012). During the 1970s and 1980s adobe brick ${ }^{3}$, rammed earth and pressed brick houses were built, the latter made using a Cinva Ram press ${ }^{4}$.

Interest in earth building grew during the last twenty years of the twentieth century. Hands-on skills and design expertise grew as more houses were built and in 1988 the Earth Building Association of New Zealand (EBANZ) was established. Earth bricks were being manufactured commercially and in 1998 the New Zealand Earth Building Standards were published. The 1990s represented a golden era of building with earth, particularly amongst owner-builders. Centres of interest developed in Nelson, Tasman, Marlborough, Waiheke Island and Northland.

Placeholder map - a better one will be provided for final cut.

2 The term 'soil cement' went out of use at about this time and was replaced by 'rammed earth,' even though the mixes included up to $10 \%$ cement.

3 The term 'sun-dried bricks' was dropped in favour of 'adobe.'

4 The Cinva Ram press was developed in Colombia in 1952 for low cost housing initiatives and were manufactured under license by Fraser Engineering in Christchurch.
Building with earth has continued at a steady rate into the twentieth century. As well as adobe, rammed earth and pressed brick, other methods such as cob, poured adobe, light earth, straw clay, and lightweight adobe have been developed. In February 2020 the revised and updated Earth Building Standards will be published, this time including appendices on straw bale and light earth methods.

\subsection{Existing Literature}

Although there is no one volume dedicated to a comprehensive history of earth building in Aotearoa, there are a number of texts and databases which provide valuable historical information. These range from single chapters on the history in Mud and Man (Howard, 1992) and Out of the Ground (Allen, 1997), to significant inclusions within chapters in Old New Zealand Houses (Salmond, 1986) and Maori Houses and Food Stores (Phillipps, 1952), to passing mentions in New Zealand Architecture (Shaw, 1990) and Passion for Earth (Bridge, 2000).

Ian Bowman's 2000 paper, Earth building in New Zealand, provides a short history of earth techniques in the nineteenth century and census data on the incidence of earth buildings (Bowman, 2000). It goes on to discuss the conservation of specific structures. Other academic theses also provide concise histories in their introductions ${ }^{5}$. Earthbuilding, the quarterly magazine of EBANZ, has been published since 1989 and contains occasional articles about historic buildings and Heritage New Zealand has published magazine articles and commissioned conservation reports, on a number of historic nineteenth century earthen structures. However, it is Pātaka ${ }^{6}$, their database, of listed ${ }^{7}$ buildings which is of most interest. Miles Allen's extensive national survey completed in 1990 includes most of the Pâtaka entries but records all the 546 earthen buildings, old and new, he found when travelling the length of the country, over the summers of 1989 and 1990. His unpublished records are held by EBANZ, except those for the Otago and Southland regions which are missing. In Out of the Ground (1997), Allen used findings from his 1990 survey to construct a graph showing the incidence of surviving earth buildings in decades. Further to Allen's data, the author conducted a survey in 2010 of all earthen and straw bale houses constructed since 1945 in the Nelson/Tasman district. The author's on-going research has resulted in two conference papers about earth building from 1945 to 1965 (Hall, 2017, 2019)

Apart from the histories mentioned above, content for a comprehensive history, will be sourced from primary research, published and unpublished texts, and archival information. Books, such as Puawananga (Larkin, 1947) and Mud in Our Eyes (Stephens, 1981), tell the stories of individuals constructing their own earth houses. Papers by Morris and Walker. on the performance of earthen structures following the Canterbury earthquakes provide further information (Morris, 2011). Other valuable sources are the National Library of New Zealand's online resource, Papers Past, which provides ready access to digitised newspapers, magazines, letters and diaries from the nineteenth and twentieth centuries, provincial museums, and Archives New Zealand which stores the historical records of government departments.

\footnotetext{
5 Examples are Allen, XX, Jackson, and Scrivener.

6 ' Pātaka' is the name for a Māori food storehouse.

7 Listed buildings are those which have been given a heritage status of Category 1 or 2, 1 giving the highest protection.
} 


\section{OTHER HISTORIES: LITERATURE REVIEW}

\subsection{Selected Literature}

The selection of texts for investigation was made based on their potential to inform the structure of the proposed history of earth building in Aotearoa New Zealand. Some texts are histories themselves or include histories, while others are about contemporary practice. Some are concerned solely with Aotearoa while others have no New Zealand content. Between them they present a range of organisational structures and a variety of presentation formats.

\section{Selected texts are:}

Colonial Architecture in New Zealand (Stacpoole, 1976) presents a history of European architecture in New Zealand from 1809 to the 1880 s. It is primarily concerned with public buildings and houses designed by architects.

Old New Zealand Houses 1800-1940 (Salmond, 1986) provides a comprehensive record of ordinary houses: materials and methods of construction, planning and form, decoration and style.

New Zealand Architecture: From Polynesian Beginnings to 1990 (Shaw, 1991) is predominantly concerned with the development of architecture via buildings designed by architects, except for the introductory chapter which discusses early Māori and settler housing.

Out of the Ground: Earth Building in New Zealand (Allen, 1997) begins with a brief history and goes on to discuss various techniques, old and new, soil testing and design issues.

Māori Houses and Food Stores (Phillipps, 1952) uses archival written and photographic material to record building techniques and typologies for the houses and food stores of Māori throughout Aotearoa from the first days of European settlement to the first half of the twentieth century.

Māori Architecture: from fale to wharenui and beyond (Brown, 2009) is set out in seven chapters and tells the story of the evolution of Māori architecture from Polynesian beginnings through ever-changing adaptations to a twenty-first century bicultural environment.

Crafting Aotearoa: A Cultural History of Making in New Zealand and the Wider Moana Oceania (Chitham et al., 2019) chronicles the development of many art and craft practices such as weaving, furniture making, glass, ceramics, over a wide geographic area and encompassing many traditions.

Mud and Man: a history of earth buildings in Australasia (Howard, 1992) provides a state-by-state history and includes one chapter on New Zealand.

Earth Architecture (Rael, 2009) is divided into four chapters defined by technique. Each chapter begins with an essay describing the technique and its evolution, and follows with well-photographed architectural case studies all built post 1970 .

Encyclopedia of Vernacular Architecture of the World $(E V A W)$ (Oliver, 1997) is set out in three substantial volumes. The first discusses theories while volumes two and three chronicle different vernacular traditions from around the globe.
Atlas of Vernacular Architecture of the World (AVAW) (Vellinga et al., 2007) provides cartographic support for EVAW showing contextual information such as climate, vegetation and religion, and the geographic distribution of various traditions, thereby allowing comparisons to be made.

\subsection{Structure of Texts}

Four main structural divisions have been identified in the eleven texts shown in Table 1: chronological, regional, technique, and typology. Each of the texts has used a hierarchy of up to three of these divisions.

As one might expect in a history, many books use chronology as the primary division with content ordered thematically in sequential chapters. For instance, Crafting Aotearoa has eight chapters; the first two, entitled "Crafting and island nations" and "Crafting on board," cover the making traditions both Pasifika people and Europeans have brought to Aotearoa. New Zealand Architecture also uses thematic titles as in "The Architecture of Prosperity" and "The Search for the Vernacular."

\begin{tabular}{|l|l|l|l|l|}
\hline & & & & \\
& & & \\
\hline Colonial Architecture & 1 & 2 & & \\
\hline Old NZ Houses & 1 & & 2 & 3 \\
\hline NZ Architecture & 1 & & & 2 \\
\hline Out of the Ground Chapter 1 & 1 & & & \\
\hline Māori Houses and Food Stores & 3 & $2 *$ & $2^{*}$ & 1 \\
\hline Māori Architecture & 1 & $2 *$ & & $2^{*}$ \\
\hline Crafting Aotearoa & 1 & & & \\
\hline Mud and Man & 2 & 1 & & \\
\hline Earth Architecture & 2 & & 1 & \\
\hline EVAW (V2 \& 3) & & 1 & & \\
\hline AVAW & & 1 & $2 *$ & $2^{*}$ \\
\hline LEGEND: 1- Primary, 2 - Secondary, 3-Tertiary, \\
2* - more than one secondary sub-division is used. \\
\hline
\end{tabular}

Table 1. Structural hierarchy of histories and records

Three texts use regions as their primary division. Notably they all cover large areas; for $E V A W$ and $A V A W$ the entire planet and Mud and Man covers Australia and New Zealand. Neither $E V A W$ or $A V A W$ purport to be a history, it is therefore unlikely that any basic structure other than the chosen one would be appropriate. On the other hand, Mud and Man is a history and chronology is important, hence it is used as the secondary division within each chapter. It might well have been structured the other way round with time periods first and regional divisions for each period. As it is, the particular techniques that developed in different regions, such as pisé in New South Wales and adobe brick in Victoria, come to the fore. However, both systems were used in both states and a chapter arrangement defined by chronology may have produced a different story, one that illustrated similarities for different time periods.

Earth Architecture is the only work in the study group that uses technique as its primary division. Rael limited his case studies to a forty-year period, 1970 to 2008, but the essays that introduce each chapter tell the story of the particular 
material in chronologically from ancient times. The case studies are also ordered chronologically. While the book could have been structured differently, chronologically or regionally for instance, it would have told quite a different story, one that may not have worked so well for the author's "conceptual basis for the content of this book: works of architecture that employ the ancient technology of earth and are informed by the issues that affect contemporary society" (Rael, 2009, p. 14).

The only text to use typology as the main divider is Māori Houses and Food Stores which is divided into two parts, the first covering the former and the second the latter. Part I is further divided by technique, and Part II by region. Phillipps' organisation works well for the material he was working with. Although many of the archival accounts he used were dated, the provenance of what was being observed was often not. The variation in techniques makes this a difficult primary divider but the material for both houses and food stores could also have been ordered regionally.

\subsection{Media and Format}

The selected literature is made up of printed books from the period 1952 to 2019. None are available as an e-book; however, Crafting Aotearoa, the most recent publication has a sister project facilitated by Auckland Museum as an online resource on the museum's web page. The content is a collection of 50 essays "divided into six sections: Craft concepts, Glass, Textiles, Paper and metalcraft, Pottery, Jewellery and adornment, and Woodwork and furniture" (Auckland Museum, 2019). Although the website is somewhat clumsy to navigate, being part of the web page for a large organisation, the text and images within each section are arranged in a crisp and clear manner, well suited to screen viewing.

\begin{tabular}{|c|c|c|c|}
\hline Publication & Date & Columns & Images \\
\hline $\begin{array}{l}\text { Colonial } \\
\text { Architecture }\end{array}$ & 1976 & 1 & $\mathrm{~B} / \mathrm{W}$ \\
\hline Old NZ Houses & 1986 & $1 \& 2 * 1$ & $\mathrm{~B} / \mathrm{W}$ \\
\hline NZ Architecture & 1991 & $\begin{array}{l}3 \text { ( }^{\text {rd }} \text { for } \\
\text { citations) }\end{array}$ & $\mathrm{C} \& \mathrm{~B} / \mathrm{W}$ \\
\hline Out of the Ground & 1997 & $1 * 2$ & $\mathrm{C}^{* 6} \& \mathrm{~B} / \mathrm{W}$ \\
\hline Māori Architecture & 2009 & $\begin{array}{l}2 \text { (2 }^{\text {nd }} \text { for } \\
\text { citations) }\end{array}$ & $\mathrm{C} \& \mathrm{~B} / \mathrm{W}$ \\
\hline Crafting Aotearoa & 2019 & $1,2 \& 3 * 3$ & $\mathrm{C} \& \mathrm{~B} / \mathrm{W}$ \\
\hline Mud and Man & 1992 & $1 \& 2 * 1$ & $\mathrm{C}^{* 6} \& \mathrm{~B} / \mathrm{W}$ \\
\hline $\begin{array}{l}\text { Māori Houses and } \\
\text { Food Stores }\end{array}$ & 1952 & 1 & $\mathrm{~B} / \mathrm{W}$ \\
\hline Earth Architecture & 2009 & $2 \& 3 * 4$ & $\mathrm{C} \& \mathrm{~B} / \mathrm{W}$ \\
\hline $\begin{array}{l}\text { EVAW (Volumes } 2 \\
\text { and 3) }\end{array}$ & 1997 & $\begin{array}{l}3 \text { ( }^{\text {rd }} \text { for } \\
\text { citations) }\end{array}$ & $\mathrm{B} / \mathrm{W}$ \\
\hline AVAW & 2007 & $3 * 5$ & $\mathrm{C}$ \\
\hline \multicolumn{4}{|c|}{$\begin{array}{l}\text { Notes: } \\
{ }^{* 1} \text { Mostly } 2,1 \text { for larger images } \\
* 2 \text { Text wrapping for some images } \\
* 31 \text { for some images, } 2 \text { for main text, } 3 \text { for inserted sub- } \\
\text { stories } \\
* 42 \text { columns for essays, } 3 \text { for case studies where all words } \\
\text { and drawings are on the left hand page and colour } \\
\text { photographs on right hand page } \\
* 5 \text { Images cross over } 2 \text { and } 3 \text { columns } \\
* 4 \text { pages of colour plates in gloss }\end{array}$} \\
\hline
\end{tabular}

Table 2. Format of texts
The eleven texts vary in size from Māori Houses and Food Stores at $165 \mathrm{~mm} \times 245 \mathrm{~mm}$ to New Zealand Architecture at $270 \mathrm{~mm} \times 305 \mathrm{~mm}$. All except Earth Architecture, which is square, have a portrait format. All are reasonably lightweight and could comfortably be read in bed, except the three weighty tomes comprising the EVAW.

Prior to the turn of the century most books had only black and white photographs but all those written in the past twenty years have colour as well, see Table 2. Many use drawings ranging from the loose freehand sketches in Out of the Ground, to Salmond's highly detailed axonometric drawings in Old New Zealand Houses, to the crisp CAD drawings in Earth Architecture. The differing techniques say a lot about the authors and their audience. The sketches in Allen's Out of the Ground suit his highly personal account, and audience of predominantly earth-building enthusiasts. Salmond's drawing skill is admired by other architects and his use of cut-away axonometric drawings makes them easy to decipher by a wider audience, all those interested in the history of houses.

Apart from the $A V A W$, Mud and Man is the only book in the study group to use maps; to show the incidence of earth buildings in New Zealand and in each state of Australia. In the $A V A W$, each map is accompanied by text which provides further information allowing comparisons to be drawn. For instance, the text accompanying the global map "Sun-dried brick: diffusion" describes brick-making processes, history and spread of use, and contemporary practice. The maps are a useful tool allowing comparisons to be made. For instance, one can compare particular techniques with climate, cultural practices and geography.

\subsection{Summary}

The most appropriate structure and format for a history or record is clearly dependent on the subject matter, the story the author wishes to tell, and the available material. The structure determines how the story is told. It is not surprising that most histories use chronology as the primary divider, that is the nature of a history. However, it is equally appropriate to use it as a secondary divider when the subject matter is confined to a particular period, as for Earth Architecture, or covers a large area, as in Mud and Man. For the EVAW and $A V A W$, which are records rather than histories, chronology gets only a mention. The samples which use regional, technique or typology as their primary divider have particular conditions that have resulted in that choice; geographical spread of subject matter, the intention of the author, and the nature of the material.

How, then, would a New Zealand earthen history be structured?

\section{STRUCTURING A NEW ZEALAND HISTORY}

Any decision regarding the structure of a history of earth building in Aotearoa must start with a clear idea of the intention of the book followed by an analysis of the available material. The intention is to record the past and continuing use of earth as a building material, drawing attention to its value as part of the cultural heritage of Aotearoa and its contemporary relevance as a low carbon material in the face of climate change and growing populations.

Currently there is no comprehensive history but there are partial histories and records of individual buildings or groups of buildings as discussed in 2.2. Existing Literature. 
In order to analyse the material and identify knowledge gaps, it has been investigated by looking at different options for primary structure and how other histories are structured. As the vast majority of earthen buildings in Aotearoa are one typology, houses, it has not been considered as a structural division.

\subsection{Primary Structure: Chronological}

There is an undeniable logic in using chronology as the primary structure for any history. Both Salmond and Shaw have divided their histories into similar time periods, but because Shaw includes more than houses and covers a further fifty years, he has seven chapters as opposed to Salmond's three. Salmond divides the history into three distinct eras: 1800-1860, 1860-1910, and 1910-1940. These divisions coincide with distinct periods in the history of Aotearoa: the arrival and settling of Maori, and 800 years later Europeans; the colonial era lasting until 1907 when New Zealand ceased being a colony of the British Empire and became a Dominion; and lastly the period including both World Wars. Both books begin with Māori housing. As Shaw says, "A history of the architecture of New Zealand must begin with the buildings of the tangata whenua, the people of the land" (Shaw, 1991, p. 10). Shaw also uses themes such as "The Search for the Vernacular," and "Experiment, Debate and Demolition." The structural divisions used by both Salmond and Shaw are a useful starting point for a history of earth building, as are Shaw's use of thematic titles.

Table 3 shows a possible outline for a chronologically structured New Zealand earth building history. The first chapter would cover Māori and early settler buildings; the second would be brief in terms of surviving buildings but would include discussions about earth and reports of overseas developments from local newspapers. The handful of bespoke houses from that period could also be discussed; for instance, the clay block house designed by J.W. Chapman-Taylor in 1923 (Allen, 1997). Chapter three would cover the optimistic return to earth after WW2 and its subsequent slow-down. There is a wealth of material for chapters four and five bringing the history up to the present.

\begin{tabular}{|l|l|}
\hline \multicolumn{1}{|c|}{ Option C } \\
\hline 1 & Early Earth 800 -1900 \\
\hline 2 & Fading Earth 1900-1945 \\
\hline 3 & Back to Earth 1946-69 \\
\hline 4 & Earth Renaissance 1970- 1999 \\
\hline 5 & 21st Century Earth 2000-2020 \\
\hline
\end{tabular}

Table 3. Potential chronological primary structure

A chronological history would highlight the persistence, or not, of various techniques and of earth building in different regions. If this option was taken, the question would then be how to further break the material down; by region or technique.

\subsection{Primary Structure: Regional}

When a text uses regions as the primary division, as in Mud and Man, similarities of construction type within particular regions become evident. This is also evident in Allen's database which is set out in regions, making it clear that certain areas have a predominant technique; adobe in Central Otago and cob in Canterbury, for instance. His database also provides clear evidence that some regions have a more substantial earthen heritage than others, at least prior to $1990^{8}$. The South Island had more than four times the number of buildings than those in the North Island.

Table 4 shows an option for a regional primary structure going from north to south, which is also the order in which New Zealand was settled by both Māori and Europeans. Chapters one to four cover the North Island and five to seven cover the South Island.

\begin{tabular}{|l|l|}
\hline \multicolumn{2}{|c|}{ Option R } \\
\hline 1 & Northland, Auckland \\
\hline 2 & Waikato, Thames/Coromandel, Bay of Plenty \\
\hline 3 & East-coast North Island \\
\hline 4 & Wellington, Whanganui, Taranaki \\
\hline 5 & Marlborough, Nelson, Tasman \\
\hline 6 & Canterbury, Westland \\
\hline 7 & Otago and Southland \\
\hline
\end{tabular}

Table 4. Potential regional primary structure

There are clear advantages to structuring a New Zealand history by region. For example, it would open up discussions as to why certain regions have a richer earthen heritage. Is it to do with climate, soil type, available resources, or the skills of the inhabitants? However, a decision would have to made as to whether regional should be the primary, secondary or tertiary structure.

\subsection{Primary Structure: Technique}

Earth Architecture is the only text in the study group to use technique for its primary division. The case studies which follow the essays for each of the four methods are in chronological order. Although there is no overt regional division, particular regional similarities do become obvious. For instance there are seven projects from Australia in the rammed earth chapter and none in any other category.

\begin{tabular}{|l|l|}
\hline \multicolumn{2}{|c|}{ Option T } \\
\hline 1 & $\begin{array}{l}\text { Introduction including Māori methods, Sod and } \\
\text { Wattle and Daub }\end{array}$ \\
\hline 2 & Cob \\
\hline 3 & Unstabilised Adobe or Sun-dried brick \\
\hline 4 & Pisé and Rammed Earth \\
\hline 5 & Stabilised and Pressed Earth Brick \\
\hline
\end{tabular}

Table 5. Potential technique primary structure

Table 5 shows possible chapter headings for a New Zealand history based on technique. The introduction, would include discussion of methods that are no longer used except in heritage restoration projects. Chapter two would include projects built in the nineteenth century, but none in the twentieth, apart from restoration projects, and only a handful in the twenty-first century. This is something that might not be so obviously picked up when using other primary and secondary divisions. Chapters three and four would also begin in the first half of the nineteenth century and carry through to the present day. Chapter five would start in the middle of the twentieth century, when cement began to be included in the mix, and continue to the present day.

8 At the 2010 EBANZ conference on Waiheke Island near Auckland, it was reported that over 30 earthen buildings have been built since Allen's survey. 
Technique as the primary structure works well for Rael's restricted time period and his core intention: to illustrate the potential of earth as a contemporary building technique. While this is also important for the proposed New Zealand history, it is secondary to the overiding aim to record the past and continuing use of earth, for which either a chronological or regional primary structure seems preferable. However technique could be a useful secondary or tertiary division.

\subsection{Format}

Although the particularities of format would require collaboration with a publisher and are not a vital element of this paper, they need to be considered when thinking about the structure. The different formats of the eleven texts listed in Table 2, help inform options for a New Zealand history, regarding size of book, relationship of text to images, the images themselves, and the inclusion of sub-stories or case studies which may be about particular buildings, techniques or characters.

The scope of the topic means that any publication will not be as large as Crafting Aotearoa or the EVAW or AVAW. Out of the Ground, Earth Architecture and Māori Architecture have 200 pages and are no larger than $220 \mathrm{~mm}$ x $270 \mathrm{~mm}$, a more appropriate size given the material available.

All the twenty-first century publications have high quality colour photographs for surviving buildings and artefacts. Where archival black and white images have been used, they have been enhanced, and all drawings are also of a high quality. So, too, would images and drawings for the proposed history need to be of a high quality. Where surviving buildings that are important to the narrative have fallen into disrepair, as is the case for some of the mid-twentieth century houses, it may be prudent to use drawings and archival photographs instead of up-to-date colour photographs.

The use of maps in the $A V A W$ demonstrates their value, and potential for the proposed history. Whether the intended audience is national or international, maps that locate the different regions, climates, soil types and incidence of earth buildings could be located within the text or as appendices.

Earth Architecture and Crafting Aotearoa include case studies or sub-stories, which are vital elements of both works, enriching the narrative. This format allows for both in-depth reading of the entire narrative, or intermittent browsing; as one would expect in a coffee table book. In Earth Architecture, chapter essays are printed on sepia-toned paper and the case studies that follow are on white. In Crafting Aotearoa, sub-stories are treated as block insertions, identified by a different font colour, within the lead story that ties each chapter together. Both texts use one or two columns for the essays and lead stories, and three for the case studies and sub-stories, see Table 2. For an earthen history, the sub-stories would be about characters, like Alley and North, particular buildings, such as the 1923 Chapman-Taylor house or one built by Charlotte Preston Larkin in 1944, and particular techniques, if the adopted structure means that they are not part of the main text.

\subsection{Proposal}

The foregoing analysis suggests that the primary division for a New Zealand history should be either chronological or regional. Table 5 shows four options for consideration. Returning to the intention of the project: "to record the past and continuing use of earth as a building material, drawing attention to its value as part of the cultural heritage of Aotearoa, and its contemporary relevance as a low carbon material in the face of climate change and growing populations," it is clear that the continuum is important. This suggests that chronology should be either the primary or secondary division, therefore S4 is eliminated.

\begin{tabular}{|l|c|c|c|c|}
\hline \multicolumn{1}{|c|}{ Level } & S1 & S2 & S3 & S4 \\
\hline Primary & $\mathrm{C}$ & $\mathrm{C}$ & $\mathrm{R}$ & $\mathrm{R}$ \\
\hline Secondary & $\mathrm{R}$ & $\mathrm{T}$ & $\mathrm{C}$ & $\mathrm{T}$ \\
\hline Tertiary & $\mathrm{T}$ & $\mathrm{R}$ & $\mathrm{T}$ & $\mathrm{C}$ \\
\hline $\begin{array}{l}\text { C: Chronological } \\
\text { R: Regional } \\
\text { T: Technique }\end{array}$ & \multicolumn{5}{|l}{} \\
\hline
\end{tabular}

Table 5. Options for structuring a New Zealand history

Regional differences are also important, but some of these differences have changed over time. For instance, sun-dried brick was the predominant method used in Central Otago until the mid-twentieth century, whereas in later years rammed earth has become more common. Better connectivity between regions and greater understanding of earthen materials has also meant that a variety of methods are often found within one region. Onsite soils can be modified by adding other ingredients; sand when soil for rammed earth has too much clay, or clay when soil for adobe bricks does not have enough. These changes are an important part of the history and would be best reflected with regional as the primary or secondary division.

A disadvantage in having a regional primary division is that for many areas, like the central North Island and the west coast of the South Island, there is little or no earthen heritage. However, having regional as the secondary division would provide the opportunity to discuss regionally specific situations; such as the paucity of timber in Central Otago until exotic forests were established and improved transport linkages meant it became easier to bring timber in from other areas. A chronological primary division would make it easier to discuss the place of earth building, its cultural relevance, in relation to historical events or movements which affected the whole country: material shortages after World War Two, and rising environmental consciousness, for instance. If it were the secondary division that kind of information would need to be repeated for each region. For these reasons S1 with a chronological primary division and regional second division is considered the best option. It is also possible that both regional and technique be used as secondary subdivisions for different time periods as it was in Maori Houses and Food Stores.

In terms of format, the intention is to appeal to a wide audience including; anyone interested in earth construction and the history of the built heritage of Aotearoa, and design professionals and students. The format needs to allow for an over-riding or linking narrative supporting individual case studies and sub-stories; Crafting Aotearoa and Earth Architecture are contemporary exemplars of how this might be achieved. To test the proposed S1 structure, Table 6 lists possible case studies or sub-stories for each chronological chapter ordered by region from north to south. They have been chosen to demonstrate the techniques used during the time period and in all cases there are more possible options than those chosen for this exercise. A similar table could be drawn up for arranging the case studies by material, but either way the case studies can be written before making a final decision on the secondary structure. 


\begin{tabular}{|l|l|}
\hline Chapter & Case studies and sub-stories \\
\hline Early Earth & $\begin{array}{l}\text { Pompallier House in Northland, a pisé } \\
\text { missionary building specifically built for } \\
\text { printing bibles in 1842; a number of cob } \\
\text { buildings in Nelson, Marlborough, and } \\
\text { Canterbury; a number of sun-dried brick } \\
\text { buildings in Central Otago including the }\end{array}$ \\
$\begin{array}{l}\text { Hayes Engineering Works and the gold- } \\
\text { mining township of St Bathans. }\end{array}$ \\
\hline $\begin{array}{l}\text { Fading } \\
\text { Earth 1900- }\end{array}$ & $\begin{array}{l}\text { Charlotte Preston Larkin sun-dried brick } \\
\text { house, Northland; Chapman-Taylor clay block } \\
\text { house, Auckland; Waihopai Valley sun-dried } \\
\text { brick house, Marlborough; Hororata rammed } \\
\text { earth house, Canterbury; Jack Haig sun-dried } \\
\text { brick houses, Central Otago. }\end{array}$ \\
\hline $\begin{array}{l}\text { Back to } \\
\text { Earth 1948- } \\
1970\end{array}$ & $\begin{array}{l}\text { Anker Jones' soil cement houses, Whanganui; } \\
\text { Wellington; Riverside community rammed } \\
\text { earth houses and hall, Nelson; Alley and soil- } \\
\text { cement houses, Christchurch, Haig sun-dried } \\
\text { brick houses, Central Otago. }\end{array}$ \\
\hline $\begin{array}{l}\text { Earth } \\
\text { Renaissance } \\
1971-1999\end{array}$ & $\begin{array}{l}\text { Yvonne Rust rammed earth house, Northland; } \\
\text { Sans Souci Adobe Inn, Tasman; Olorenshaw } \\
\text { adobe house, Nelson; Waddy rammed earth } \\
\text { house, Marlborough; Pressed earth brick houses, } \\
\text { Canterbury; Adobe house, Central Otago. }\end{array}$ \\
\hline $\begin{array}{l}\text { Twenty-first } \\
\text { century } \\
\text { Earth 2000- } \\
2020\end{array}$ & $\begin{array}{l}\text { Rore Kāhu rammed earth memorial, } \\
\text { Eorthland; North cob house, Auckland; } \\
\text { buildings, Auckland; Stabilized adobe house, } \\
\text { Waiheke Island; Olorenshaw adobe house, } \\
\text { Cambridge; Maeder adobe house, Nelson, } \\
\text { Tonto cob cafe, Tasman; Assembly rammed } \\
\text { earth house, Central Otago. }\end{array}$ \\
\hline
\end{tabular}

Table 6. Case studies for S1: chronological primary and regional secondary divisions

\section{CONCLUSION}

This paper set out to investigate possible structures for a history of earth building in Aotearoa New Zealand. A selection of New Zealand and international publications were interrogated to identify different structural hierarchies and formats. These were then applied to the New Zealand scenario using historical information from a variety of sources. A chronological primary division was found to be the most appropriate, with themed chapters further subdivided into regions. Case studies and substories would be treated as essential elements of the narrative, as has been done successfully in two twenty-first century texts, Earth Architecture and Crafting Aotearoa. These elements could be inserted either within the body of a chapter or as a group of separate entities after the main narrative. Either way, these insertions are essential for expressing the importance and unique nature of New Zealand's earth building heritage and, with the later entries, the contemporary relevance of earth as a low carbon building material.

\section{ACKNOWLEDGEMENTS}

Progress on this project would not have been possible without the generous support of the School of Architecture and Research Office at Unitec Institute of Technology, or the Earth Building Association of New Zealand, in particular Graeme North.

\section{REFERENCES}

Allen, M., 1991: Survey of earth buildings in New Zealand. Unpublished document held by the Earth Building Association of New Zealand.

Allen, M., 1997: Out of the Ground-Earth Building in New Zealand. The Dunmore Press, Palmerston North.

Auckland Museum, 2019: Crafting Aotearoa. https://www.aucklandmuseum.com/discover/research/craftingaotearoa

Bowman, I., 2000: Earth Building in New Zealand: a little known heritage. Terra 2000: $8^{\text {th }}$ International Conference on the Study and Conservation of Earthen Architecture. James and James, London.

Bridges, M., North, G., 2000: Passion for Earth: Earth Houses in New Zealand. David Ling, Auckland.

Brown, D., 2009: Māori Architecture: from fale to wharenui and beyond. Penguin Group (NZ), Auckland.

Chitham, K., Māhina-Tuai, K. U., Skinner, D., 2019: Crafting Aotearoa: A Cultural History of Making in New Zealand and the Wider Moana Oceania. Te Papa Press, Wellington.

Hall, M., 2012: Earth and Straw Bale: an investigation of their performance and potential as building materials in New Zealand. M.Arch thesis, Victoria University of Wellington. New Zealand.

Hall, M., 2017: Mid-century earthen architecture in Aotearoa New Zealand - a new vernacular? Vernacular and Earthen Architecture: proceedings of SosTierra 2017, ed C. Mileto et al., CRC Press/Balkema, Leiden. 135- 140.

Hall, M., 2019: Back to earth: earth building in Aotearoa New Zealand 1945-65. In Andrew Leach and Lee Stickells (Ed.), SAHANZ - Distance Looks Back, Vol. 36. 205-216.

Howard, T., 1992: Mud and Man. Earthbuild Publications, Melbourne.

Jackson, E., 2009: Self reliance and earth building in New Zealand: a case-study of the struggle between sustainability and consumerism. M. Arch thesis, University of Auckland, New Zealand.

Larkin, C., 1947: Puawananga: The Adobe Cottage. The Northern Publishing Company, Whangarei.

Morris, H. \& Walker, R. 2011. Observations of the performance of earth buildings following the February 2011 Christchurch earthquake. Bulletin New Zealand Society for Earthquake Engineering, Volume 4, No.4. NZSEE: Wellington.

Oliver, P., 1997: Encyclopedia of Vernacular Architecture of the World. Cambridge University Press, Cambridge.

Phillips, W. J., 1952: Maori houses and food stores. Government Printer, Wellington.

Prickett, N., 2016: Fortifications of the New Zealand Land Wars. New Zealand Department of Conservation, Wellington. https://www.doc.govt.nz/globalassets/documents/science-andtechnical/sap261_1._introduction.pdf 
Rael, R., 2009: Earth Architecture. Princeton Architectural Press, New York.

Salmond, J., 1986: Old New Zealand Houses 1800-1940. Reed Methuen., Auckland.

Shaw, P., 1991: New Zealand Architecture: From Polynesian Beginnings to 1990. Hodder and Stoughton, Auckland.

Siers, J., 2007: The Life and Times of James Walter ChapmanTaylor. Millwood Heritage Productions, Wellington.

Stacpoole, J., 1976: Colonial Architecture in New Zealand. A.H. and A.W. Reed, Wellington.

Stephens, M and N., 1981: Mud in Our Eyes. The Tin Pot Press, Christchurch.

Vellinga, M., Oliver, P., Bridge, A., 2007: Atlas of Vernacular Architecture of the World. Routledge, Oxford. 